Discussion

Papers
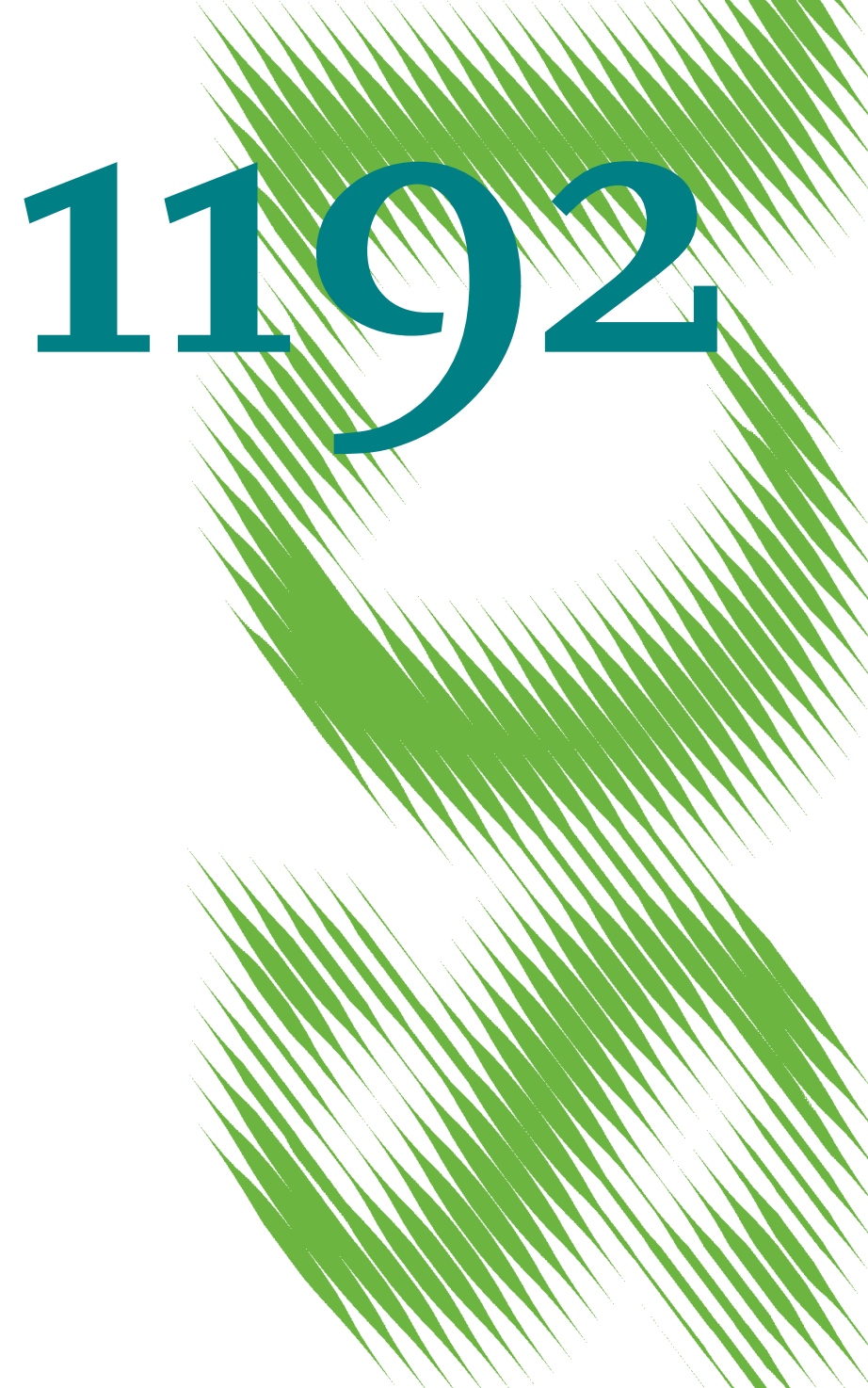

MIMMMMMMMM

Implications of Mandatory

Registration of Mobile Phone Users in Africa 
Opinions expressed in this paper are those of the author(s) and do not necessarily reflect views of the institute.

IMPRESSUM

(C) DIW Berlin, 2012

DIW Berlin

German Institute for Economic Research

Mohrenstr. 58

10117 Berlin

Tel. $+49(30) 89789-0$

Fax +49 (30) $89789-200$

http://www.diw.de

ISSN print edition $1433-0210$

ISSN electronic edition 1619-4535

Papers can be downloaded free of charge from the DIW Berlin website:

http://www.diw.de/discussionpapers

Discussion Papers of DIW Berlin are indexed in RePEc and SSRN:

http://ideas.repec.org/s/diw/diwwpp.html

http://www.ssrn.com/link/DIW-Berlin-German-Inst-Econ-Res.html 


\title{
Implications of Mandatory Registration of Mobile Phone Users in Africa*
}

\author{
Nicola Jentzsch ${ }^{\dagger}$
}

March 1, 2012

\begin{abstract}
Sub-Saharan Africa ranks among the top regions in terms of growth in the number of mobile phone users. The success of mobile telephony is attributed to the opening of markets for private players and lenient regulatory policy. However, markets may be increasingly saturated and new regulations introduced across Africa could also have a negative impact on future growth. Since 2006, the majority of countries in the region have introduced mandatory registration of users of prepaid SIM cards with their personal identity details. This potentially increases the costs of using mobile telephony. I present a fixed effects model for the estimation of the impact of mandatory registration on mobile penetration growth, which is based upon a panel dataset of 32 countries in Sub-Saharan Africa for the years 2000 to 2010. The results show that the introduction of mandatory registration depresses growth in mobile penetration.
\end{abstract}

JEL-Classification: L96, L98, D18.

Keywords: Telecommunication; government policy; consumer protection; privacy.

${ }^{*}$ The author is indebted to a number of people for their review and helpful suggestions. These are in particular Tobias Schmidt, Susan Steiner, Yiannis Theodorou, and Pio Baake. Moreover, for the provision of data, the author thanks Jenny Aker and Christoph Stork. The paper presents preliminary results, comments are welcome.

${ }^{\dagger}$ DIW Berlin, Mohrenstrasse 58, 10117 Berlin, T. +49 30 89789-234, F. +49 30 89789-103, njentzsch@diw.de. 



\section{INTRODUCTION}

Mobile phone usage is regarded as one of the economic success stories in Africa. According to a report of the International Telecommunications Union (ITU), the mobile industry invested US\$ 35 billion between 2000 and 2011, providing more than 67 percent, or 500 million people in Sub-Saharan Africa with mobile coverage (International Telecommunication Union [ITU], 2011, p. 65). According to ITU statistics, growth rates in mobile cellular subscriptions per 100 inhabitants (2005-2010) were on average about 44 percent p.a. across 47 Sub-Saharan African countries, excluding Guinea and South Sudan. However, growth rates might cool off noticeably in the near future. The reason could be a new measure introduced in more than half of SubSaharan countries: the mandatory registration of users of mobile phones with personal details for prepaid SIM cards. Such registration had not been conducted in the past, but is now required by many governments in response to rising crime and fraud schemes involving mobile phones. The main justification for the measure is to combat crime, to prevent fraud and to support AntiMoney Laundering and the Combating of the Financing of Terrorism (AML/CFT) measures.

Registration policies were first introduced in 2006 in both Senegal and Mauritius. In 2008 Botswana, Burkina Faso, Democratic Republic of the Congo and Sudan followed suit and implemented similar policies. After these early adopters, a wave of more than 20 countries followed in 2009 and 2010. The initiative is lead in the East African Community by the Assembly of Telecommunications Operators at the East African Communications Organisation (EACO), an intergovernmental body of telecom regulators, telecom and postal operators. It is reported in the African media that this required registration might negatively affect mobile subscriber growth rates. ${ }^{1}$ For example, registration could lead to the disconnection of millions of SIM cards, as Africans struggle to assemble the required formal identity documentation. Moreover, there could be also a negative impact on the operators' revenues as mandatory registration leads to an immediate drop in the number of active SIM cards after the registration deadline passes. The measure may also influence telecom operators' competition by increasing switching costs. For consumers, the services will become personalized in future, because they are no longer anonymous. Gow and Parisi (2008, p. 65-66) note that it is, in general, difficult to achieve total anonymity in mobile telephony, therefore the term anonymity is used herein to represent 'non-registration,' i.e. the absence of specific personal identity information. Registration will also alter the types

\footnotetext{
${ }^{1}$ AfricaNews.com (2010).
} 
of crime encountered in the markets with a predictable increase in identity-related crimes. In order to estimate the impact of mandatory registration on mobile penetration growth, a fixed effects model is estimated controlling for GDP growth and governance variables as well as market saturation. The model is estimated using a panel dataset of 32 African countries for the years 2000 to 2010 . The hypothesis tested is that mandatory registration negatively impacts on mobile phone penetration growth. The evidence should be regarded as preliminary considering that policy changes were only introduced starting in 2006. There is little known about the impact of mandatory registration of prepaid SIM card users in Africa, and the sheer size of the markets merit investigation. This article, therefore, fills a void at the intersection of different literature strands. There is a vast literature on mobile phone diffusion in Africa such as Aker and Mbiti (2010), ITU (2011) and Minges (1999), to name but a few. Moreover, there is some analytical work on customer loyalty, switching costs and churn in post-paid mobile telephony services in industrialized countries (Chuang, 2011; Maicas, Polo \& Sese, 2009). However, the author is not aware of academic studies estimating the impact of mandatory user registration in Europe on prepaid services. Moreover, in Africa the prepaid market segment is much larger than in Europe-such that one would expect more pronounced effects in Africa. There is a small, yet growing, technical literature on churn prediction in prepaid telephony services (Dasgupta, Singh \& Viswanathan, 2008; Owczarczuk, 2010). However there appear to be no studies on mandatory registration and its impact on competition among telecom operators.

This paper is not intended to be a full-scale cost-benefit analysis of mandatory registration, because registration was only relatively recently introduced. The benefits of such measures are typically stressed by governments to improve the detection of crime and fraud in law enforcement. At this stage, there is no convincing empirical evidence that mandatory registration in fact systematically lowers crime rates. Another benefit stressed is that registration could improve the migration of prepaid customers to mobile financial services for which customers have to be identified. On the other hand, there are drawbacks associated with this policy. In the past, anonymous prepaid services induced little loyalty to a specific network because it was easy to switch to another operator's network. Mandatory registration, however, could increase a customer's switching costs, because a customer has to register with each operator. Less switching impacts consumer privacy, as the personal profile with the selected operator becomes more detailed and complete. Increased switching costs cushions competition and reduce price 
discipline if consumers do not foresee that they will be potentially locked-in once they registered. In an experimental study conducted for the European Network and Information Security Agency, Jentzsch, Preibusch and Harasser (forthcoming), it is found that there is little switching between two firms after consumers filled out an online form with their personal details with one of the firms. In addition to these effects, customer registration could give rise to huge amounts of personal data collected in Africa, i.e. the real-time location of users who are now identified.

\section{The Rising Trend of Customer Registration}

Registration of users of prepaid mobile telephony is conducted in some OECD countries, but not all. The Center for Policy, Research on Science and Technology Registration (Center for Policy Research on Science and Technology [CPRST], 2006) surveyed such policies in the OECD in 2006. It reports that, at the time of the survey, 16 of 25 responding nations did not have mandatory registration policies in place including Austria, Canada, Denmark and the United Kingdom. Other countries introduced registration relatively recently: One example is Greece, which introduced the policy in late 2009. ${ }^{2}$ There are no international comparisons related to African countries, despite the success of mobile telephony there. The lack of systematic data on Africa could be a reason why the trend of mandatory registration has received little attention in the literature and in international discussions about mobile banking. ${ }^{3}$ In the following, the rationale of mandatory registration is discussed and evidence on its spread across Africa is presented. An overview of introduced registration measures in Africa is presented in Table (1), which also contains information on the country sample used herein.

\subsection{The Procedure and Rationale of Mandatory Identification}

The ITU states that there is neither official policy recommendation nor any other guideline on the obligation to conduct mandatory registration of prepaid SIM card users. ${ }^{4}$ In May 2010, the East African Communications Organization (East African Communications Organization

\footnotetext{
${ }^{2}$ It is reported in the media that the main operators in the country have seen declines in their customer base (Wood, 2010). In Greece, the economic downturn is also contributing to a decline in consumer spending.

${ }^{3}$ For example, in Chatain, Zerzan, Noor, Dannaoui, and de Koker (2011) the trend is mentioned on p. 49 and again in footnote 32, p. 60, but nothing is said about its extent. Most surprisingly, this also holds for ITU (2011).

${ }^{4}$ Personal communication with the author (August 4, 2011).
} 
[EACO], 2010, p. 17) acknowledged a report from the Assembly of Telecommunication Operators proposing a subscriber registration deadline of June 2012. This assembly is the body of the telecom operators located at the EACO, an intergovernmental body of telecom regulators as well as telecom and postal operators in East Africa. EACO is in charge of promoting and harmonizing the development of telecommunications and postal services across the East African Community. While some countries apply laws and regulations, there are others where telecom operators do registration voluntarily (Kenya) or based upon a recommendation of the regulatory body (Burundi). But this kind of information is only available for a few countries. From a user's perspective it does not matter whether the operator does it 'voluntarily' or not, what matters is that he/she must register in order to use the service. Therefore, all registration measures are labeled herein as 'mandatory registration,' because access to the service is conditioned on identification. Governments have put forth that mandatory registration is necessary for more effective detection and prosecution of crime. As Gow and Parisi (2008) explain, the central assumption is that customer data retained in a database by the operator is accessible to law enforcement agencies. However, these authors conclude that there are significant problems with the claim that mandatory registration of prepaid phone service is an effective course of action. There are essentially no robust empirical studies that show that such measures make a difference in terms of crime detection as criminals have a number of ways of circumventing the rules.

Mandatory registration is a procedure whereby individuals need to go through a process of registering a prepaid SIM card for their mobile phone in their name. The process resembles Know-Your-Customer (KYC) procedures, which are conducted by traditional targets of money laundering such as banks, insurance companies or casinos. KYC procedures are part of international AML/CFT framework set by the Financial Action Task Force (FATF). In fact some commentators have complained that, "In some instances the requirement to become a prepaid GSM customer is more rigorous than that to open a bank account in the same market!" (Scanlon, 2010, p. 43). In other cases, these procedures might be so lax that it defeats their very purpose. Whether a registration procedure is effective depends on how strict the measure is enforced and whether identification is based on proper due diligence of the employees of telecom operators.

According to KYC procedures there needs to be formal documentation and verification of the identity of the customer, i.e. customers need to provide personal details such as name, 
physical address and contact details before an institution enters into a business relationship with the customer. Where possible, the identity of the individual needs to be verified based upon government-issued identity cards or comparable documents. Where individuals cannot provide proof of physical address, for example, when they live in informal settlements, other measures may apply. In the following, South Africa, Nigeria, and Democratic Republic of the Congo (DRC) serve as examples.

\subsection{Registration Procedures in Three African Countries}

In South Africa, mandatory registration of prepaid cards became effective 1 July 2009 with the Regulation of Interception of Communications and Provision of Communication (RICA). An original deadline by the end of 2010 was postponed to mid-2011. The process sparked a discussion in the country and in fact led to the creation of a new word, a verb, because users were asked by their telecom operators to "RICA their SIM cards." Users must provide their name and surname, and bring proof of identity in the form of an identity document or passport, as well as a proof of a physical address in the form of either a bank statement or utility bill. Persons living in informal settlements may bring a letter/affidavit from a school, church or nearby retail store. The registration has to be done face-to-face with RICA-agents. The Department of Communications reported more than 37 million users or about 95 percent of mobile phone users, had registered by June $2011 .{ }^{5}$

In Nigeria, the Nigerian Communication Commission (NCC) embarked on a mission to have all mobile phone subscribers in the country registered by the end of 2011. The NCC explains on its website that the rationale for the measure is an increase in security and better statistical analysis of phone usage as well as to "enable operators to have a predictable profile about the users in their networks." ${ }^{6}$ According to the draft "regulations for the registration of telephone subscriber' of 2011, telecom operators must capture biometric and other personal data of subscribers. Biometric data refers to fingerprints and picture and personal information to name, gender, date of birth as well as residential address and nationality. Non-compliance by the operators is punishable with fines. By February 2011, the NCC reported that 11 million SIM cards

\footnotetext{
${ }^{5}$ Sources are for numbers are the following reports: For South Africa it is NetNews Publisher (2011); for Nigeria it is Balancing Act (2011).

${ }^{6}$ See website of the NCC: http://www.ncc.gov.ng/sim-registration/about-simreg.html
} 
were registered, and the procedure was supposed to be completed by 28 September 2011. By November 2011, newspaper reports in Nigeria cited the NCC's Vice-Chairman Eugene Juwah with the statement that 93 million mobile lines had been registered (Telegeography 2011).

In the $\mathrm{DRC}$, the regulations on registration measures hold in Article 5 that nationals need to be identified with an identity card or equivalent document (passport, driver's license, electoral card or student card). ${ }^{7}$ Moreover, in a related regulation, it is stated that individuals must provide their name, physical address, nationality, as well as their date and place of birth. This information, recorded on a form, must be signed and dated by the subscriber, who is legally held liable in case of false declarations (Article $4 \mathrm{~b}$ of the modification of the aforementioned regulations). ${ }^{8}$ Moreover, it is forbidden to identify persons only by means of telephone, SMS, or electronic courier (Article 2). In case of name changes, updating is legally required. While there is only a limited overview of different regulations at this stage, the Congolese seem to be more rigorous and specific in the required procedures and the consequences of non-compliance when compared to those in other countries. Yet, the DRC is more politically instable than many of the countries sampled herein. There is no information available on whether the regulators rigorously enforce the registration procedures. This is discussed in greater detail in the section on data caveats.

\section{Impact of User Registration}

One of the most important questions is whether the identification procedures required by mandatory registration affects the distribution and growth rates of mobile telephony in Africa countries. The panel dataset presented herein facilitates a better - although preliminary - understanding of the interactions.

\subsection{Aggregate Statistics}

Of the 48 countries in Sub-Saharan Africa displayed in Table (1) in the Appendix, confirmed information about existence or non-existence of registrations could be found for 32 countries.

\footnotetext{
${ }^{7}$ Arrêté interministériel n 25/CAB/MINETAT/ INTERDESEC/010/2008 et nº03 CAB/MIN/PTT/2008 du 08 mars fixant les conditions de souscription à l'abonnement téléphonique en République Démocratique du Congo.

${ }^{8}$ Arrêté interministériel $n^{\circ} \quad 068 / \mathrm{CAB} / \mathrm{MIN} /$ INTERSEC/2009, $\quad \mathrm{n}^{\circ} \quad 212 / \mathrm{CAB} / \mathrm{MIN} / \mathrm{J} / 2009, \quad \mathrm{n}^{\circ}$ $\mathrm{CAB} / \mathrm{MIN} / \mathrm{PTT} / 011 / 2009$ du 21 décembre 2009 modifiant et complétant l'Arrêté interministériel $\mathrm{n}^{\circ}$ 25/CAB/MINETAT/INTERDESEC/010/2008 et $\mathrm{n}^{\circ}$ 003/CAB/ MIN/PTT/2008 du 08 mars 2008 fixant les conditions de souscription à l'abonnement téléphonique en République Démocratique du Congo.
} 
Information for the other 16 countries was sought as well, but no indication of such a policy was found. This allows two conclusions: (a) either there is no such policy in the other countries, where the dummy can be set to zero for the years 2000 to 2010; or (b) there could be measures, but there is no publicly available information. The models are estimated based upon the assumption (b), i.e. the confirmed sample. Of the 32 confirmed countries, 29 introduced mandatory registration during the period under observation. In Table (2), the succession of these countries is displayed, showing a surge of reformers in 2009 and 2011.

INSERT Table 2 here.

In Fig.1, the percentage of prepaid subscribers in total mobile cellular subscriptions is plotted against GDP per capita (in Purchasing Power Parity in USD) for 2008. It is important to note that prepaid mobile phone subscriptions are active SIM cards and not the number of natural persons subscribing - such caveats of the data are discussed in greater detail below.

Figure 1: Share of Prepaid Subscriptions against GDP per capita (2008)

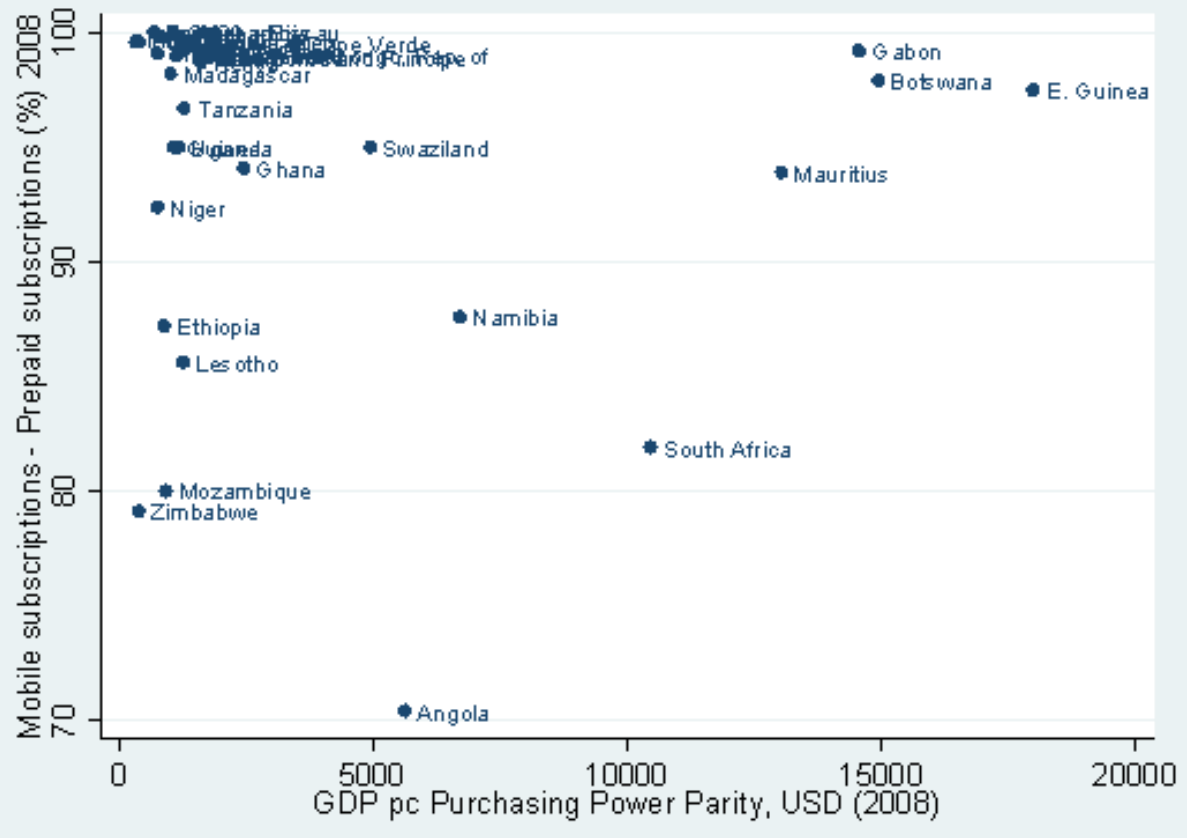

Source: ITU and CIA World Fact Book. All variables and sources are included in Table 1 in the Appendix. The Seychelles were dropped for this Figure.

The cluster of countries in the upper left corner shows that the majority of countries with low 
GDP per capita have high shares of prepaid subscriptions out of total mobile phone subscriptions. The ITU (2011, p. 22) notes that the

"introduction of prepaid billing in 1996 brought mobile to the masses. There are millions of people around the world who would not qualify for a post-paid mobile plan, let alone be able to afford the required monthly payments. The majority of subscriptions in developing countries are prepaid, and in Least Developed Countries, where income levels are particularly low, 94 per cent of subscriptions were prepaid at the end of 2009."

Another reason for the success is the reduced paperwork that came with prepaid SIM cards, as, at the time, no registration was necessary for these cards. Before we proceed some notes on data caveats are indicated. As noted by other authors, these data come with caveats. ITU figures map mobile subscriptions and therefore potentially overestimate the number of mobile phone users in African countries, because individuals might hold several SIM cards (Aker \& Mbiti, 2010, p. 210). Regarding such ownership, Research ICT Africa (2008), a household survey conducted in different African countries, reports that 36.3 percent of adults (16 years+) hold more than one SIM card in Benin, 25.8 percent in Kenya, and only 2.9 percent in Mozambique. ${ }^{9}$ These datasets are unfortunately not available across the panel used for the estimations presented in this article. It must be noted that measurement error in the dependent variable can cause attenuation bias, which makes it more difficult to detect an effect. While ITU data has severe limitations, it is the only dataset available for the time period under analysis. Follow-up research would need to use household-level data. The problem is that surveys, such as FinScope or Research ICT Africa, do not ask respondents whether or not they registered their SIM cards with telecom operators.

Unfortunately, there is no information available on whether the regulators in the different countries rigorously enforce the registration procedures. Regulatory quality must, therefore, be approximated with another variable, Regq_est, in the estimations, which is discussed in section 3.3. Therefore the level of generality existing in the data collection presented herein is whether mandatory registration exists or not. Further information collection would entail interviewing telecom operators and regulators to produce primary data on the level of enforcement quality.

The regulators typically set tight deadlines for registration. This means that within a specific period, all existing users must register their SIM cards and that all new customers must also

\footnotetext{
${ }^{9}$ These are results from a household survey on ICT access and usage conducted in 12 African countries at the end of 2007 /beginning of 2008 .
} 
be identified. Once the deadline passes, active unregistered SIM cards are deactivated. This means regulatory measures are effective after the deadline expires. Once the deadline passes, the number of active SIM cards should be affected. It is reported across many African countries that millions of active SIM cards were deactivated (Musarurwa, 2011). As mentioned, there is no comparable information on whether the regulations are rigorously enforced by regulators in different countries. This can only the approximated by other variables and is, in fact, a future research question.

\subsection{Implications for Mobile Subscription Growth}

Demand for fixed line or mobile services and economic growth are invariably linked in developing countries (Garbacz \& Thompson, 2007). But as several of African countries have experienced rather high growth rates in the past, cooling off might be simply be due to market saturation. In the regressions presented below, both market saturation and governance indicators are controlled for. There should be two immediate effects with the establishment of mandatory registration: (1) a decline in the levels of mobile cellular subscriptions due to disconnections after the deadline; and (2) a decline in the growth rates of penetration, i.e. the year-to-year changes in levels of mobile cellular subscriptions due to the increasing access costs. In 2011, a decline in cellular subscriptions was reported in Côte d'Ivoire, Gabon, South Africa, and Zimbabwe. ${ }^{10}$ SIM card disconnections have taken place in Cameroon, Republic of the Congo, Ghana, and Kenya. In Zimbabwe the three network operators disconnected a combined 2.4 million prepaid subscriptions, according to the telecom regulator, such that the total number of mobile subscriptions declined from around 8.4 to 6 million. Disconnections are expected to start in Nigeria starting in 2012 .

\footnotetext{
${ }^{10}$ See Balancing Act (2011). The article suggests that for Vodafone and MTN in South Africa there were decreases in the number of active SIM cards, but revenue was not affected to the same extent as many of the cards were zero-ARPU SIM cards. ARPU is the average revenue per user.
} 


\subsection{The Model}

This section focuses on the growth in mobile subscriptions per 100 inhabitants. For ease of interpretation, year-to-year changes in mobile penetration are used as dependent variable. A Fisher-type unit-root test (based upon Phillips-Perron tests) shows that the series "total active mobile subscriptions per 100 inhabitants" is non-stationary, i.e. integrated at the order of one in levels. However, it is stationary in first differences - a conclusion drawn by other authors as well (see Lam \& Shiu, 2010). First-differencing this variable helps to avoid problems associated with using levels as dependent variable. Here, estimation results for a baseline model with country and year fixed effects (FE model) are presented in order to control for unobserved heterogeneity. Moreover, additional variables that also change over time are introduced to control for potential influencing factors. The estimation results are based on the sample of 32 countries for which information could be confirmed. In fact, estimating the models on the larger sample of 48 countries, with the unconfirmed countries set to zero does not change the results.

All variables and sources are described in detail in Table (3) in the Appendix. Equation (1) presents the model, where $y_{i t}$ is the dependent variable, i.e. the series of yearly changes in mobile penetration, the individual country is denoted by $i$ and the time is denoted by $t$ in (1):

$$
y_{i t}=\alpha_{i}+X_{i t} \beta_{1}+Z_{i} \beta_{2}+D_{i t} \beta_{3}+\beta_{4} T_{t}+\varepsilon_{i t} ; i \in\{1,2, \ldots, N\}, t \in\left\{1,2, \ldots, T_{i}\right\}
$$

Moreover, $\alpha_{i}(i=1 \ldots n)$ denotes the entity-specific intercepts, $X_{i t}$ is a vector of time-varying co-variates (regulatory quality, political stability, GDP growth, market saturation as well as market liberalization); $Z_{i}$ is a vector of time-invariant covariates (dummies denoting countries); $T_{t}$ introduces dummies for the years and $\varepsilon_{i t}$ is the idiosyncratic error term. $D_{i t}$ is the dummy variable of interest and a proxy for the 'effect-taking' of the deadline of registration. This is a time-varying dummy, which is 0 before the deadline, 0 during the calendar year in which the deadline becomes legally binding and 1 in the following calendar year. There are two reasons behind this approximation:

(1) In the majority of countries, the registration deadline lies in the second half of the year, often in December, such that the binding character becomes effective only with the start of the next year. In some countries, deadlines were postponed from the middle of the year to its end, such that there was a delay in their binding character; 
(2) The second reason is that there are no quarterly data. Therefore, effects should only show up in the data following the year, where registration became effective.

The hypothesis on the dummy's coefficient estimate is that once the deadline becomes effective, it negatively impacts in year-to-year growth in mobile penetration. The model is estimated with binary dummies for $n-1$ countries and $t-1$ years. The inclusion of yearly dummies was indicated by a Wald test.

In the Appendix, Table (4) presents the summary statistics and the correlation coefficients of the variables are displayed in Table (5). In order to control for different influencing factors, a number of independent variables were introduced, such as GDP growth, and governance indicators such as regulatory quality, political stability, as well as liberalization of the telecom market and the levels of mobile penetration as a proxy for market saturation. The results are presented in Table (6) of the Appendix. For all models, it holds that Prob $>F=0.0000$, which is the F-test suggesting that all coefficients are different from zero.

The baseline model (Model 1) is parsimonious, because it only includes three independents: GDP growth, market saturation and the dummy for mandatory registration. Models 2-4 include the additional controls. The coefficient estimate on the dummy for mandatory registration is significantly different from zero at the 5\%-level and suggests a negative relationship. Consider Model 4: as mandatory registration becomes effective, the dummy increases by one unit, which in turn reduces year-to-year changes in mobile penetration by $\approx 4.6$ mobile subscriptions per 100 inhabitants. This result is robust across different model specifications (i.e. across models 2-4) as well as for different samples, as stated above. Introducing additional controls such as telecom liberalization, regulatory quality or political stability does not change the result. If we control for these variables, GDP growth turns out not to be significant. ${ }^{11}$ The other variable that provides a positive contribution to growth rates is the level of mobile subscriptions per 100 inhabitants, which is a proxy for market saturation. Its positive contribution might be due to network externalities and greater coverage in more developed telecom markets.

\footnotetext{
${ }^{11}$ The literature is divided on how GDP growth is associated with penetration. Studies show that GDP per capita is associated with mobile penetration (Banerjee \& Ros, 2004; Waverman, Meschi \& Fuss, 2005). In Banerjee and Ros (2004) a negative correlation of GDP per capita and tele-density is found by applying panel data regression for the years 1996 to 2000. This finding confirms that the fastest growth in cellular density occurred in countries with the lowest per capita GDP.
} 


\subsection{Robustness and Diagnostics}

FE regression models are recommended where the changes in variables over time are of interest, and where a control for unobserved heterogeneity is indicated. FE uses the relationship between the variables within a country, where FE removes the effect of time-invariant factors from the dependent variables in order to obtain their net effect. In order to decide between FE and Random Effects model, a Hausman test was conducted. The reported diagnostic results refer to the full model (Model 4 in Table (6). The inclusion of time effects was decided based upon a Wald test with the null hypothesis $\left(H_{0}\right)$ that no time fixed effects are needed. The test was significant at the $5 \%$-significance level, leading to the rejection of $H_{0}$.

Potential cross-sectional dependence was analyzed by using the Pesaran CD test, which tests whether residuals are correlated across countries. The test was not statistically significant, therefore $H_{0}$ ('no cross-sectional dependence') could not be rejected. However, a modified Wald test for groupwise heteroskedasticity in the FE model led to the rejection of $H_{0}$ ('homoskedasticity'), indicating that a robust option should be used to estimate the model. ${ }^{12}$

Multicollinearity was investigated using Variance Inflation Factors (VIFs), as well collinearity diagnostics in Stata, on the variables used for estimation. The decision rule for VIFs was VIFs $>10$ and for the collinearity diagnostics a Condition Number of 15. The statistics did not indicate a severe multicollinearity problem. Moreover, when multicollinearity is a problem coefficient estimates tend to be instable if another sample is used. To check for their stability, the model was re-estimated on the full sample and on two different sub-samples, randomly drawn from the confirmed sample. It was also re-estimated on a shorter time-period for the years 2008 to 2010 . In essence, the results remain robust. ${ }^{13}$

Potential omitted variable bias was accounted for by introducing more variables in the model. There cannot be the omission of time-invariant characteristics as the FE estimation method controls for them. The conclusion drawn here is still preliminary considered the short time frame of observation, but the results suggest that introducing mandatory registration (approximated the deadline dummy) negatively affects year-to-year growth in the levels of mobile subscriptions per 100 inhabitants. This confirms the intuition and should become more pronounced in future,

\footnotetext{
${ }^{12}$ In fact, it is not indicated to use the robust and cluster option together in the Stata FE estimation, therefore the author chose clustered robust errors.

${ }^{13}$ These tests as well as the other diagnostic tests are available from the author upon request.
} 
as more data becomes available. In the following, some complementary insights on registration and competition are presented.

\subsection{Implications of Registration for Competition}

Over the past years, the structure of telecom markets in Sub-Saharan Africa has changed tremendously. In Aker and Mbiti (2010, p. 228) market structure analysis based upon Groupe Spéciale Mobile Association (GSMA) data for the years 1995-2009 shows a large decline in monopolies and an increase in the number of fully liberalized markets. By 2010, African telecom markets were characterized as highly competitive, especially in the prepaid segment (Scanlon, 2010). Customer identification procedures could potentially affect competition intensity, the reasons being targeting efforts and incentives to lock customers in, probably through loyalty programs. Low loyalty intensifies price competition due to high rates of switching. Personal registration for SIM cards bears upfront sunk costs for individuals. It has been noted that switching costs increase competition during the first period (Klemperer, 1995; National Economic Research Associates [NERA], 2003). If customers are sophisticated they will anticipate lock-in in the second period. If they foresee such lock-in, rival operators must offer them greater incentives to join their network during the first period, which intensifies competition, before the lock-in takes place. Customers are in fact often not sophisticated enough to anticipate such effects, because this would require prepaid SIM card users to know about switching costs and future targeting efforts by operators (for a discussion on short-sighted decisions, see also Loewenstein (2000). Apart from the time-costs and effort to show-up in person for registration, individuals might have psychological costs related to the disclosure of personal data to a company. In fact, these concerns are now reported in Africa. ${ }^{14}$ This would potentially introduce additional switching obstacles, based upon trust.

Many operators in industrialized countries develop strategies to avoid churn, because the costs of customer acquisition are greater than the costs of existing customer retention. Competition strategies of telecom operators change noticeably once growth rates do not compensate for churn anymore. In the future, the collection of personal data on customers will open greater possibilities for operators with respect to their competition strategies in the prepaid segment. Operators can now identify their prepaid customers and learn more about them with profiling in

\footnotetext{
${ }^{14}$ See Malakata (2010).
} 
order to create distinct marketing approaches for different customer segments (Levisse, Manuel \& Sjolund, 2008). This helps to eliminate costly and ineffective blanket promotions. In fact, it is reported from South Africa that after the introduction of registration, Vodacom managed to reduce prepaid churn from 48.1 percent in the third quarter of 2008 to 38.1 percent in the third quarter of 2009. "Customer registration together with focused loyalty programmes has resulted in overall improvement of prepaid churn for the operator." (Scanlon, 2010, p. 43). Profiling prepaid customers allows churn prediction - an interesting area of future research (Dasgupta et al. 2008; Owczarczuk, 2010). To the knowledge of the author, there is, as of 2011, no academic literature on churn prediction in African prepaid markets. While churn occurs for many reasons, the switching to a competitor's network just being one of them, a decline should be noticeable in the period following mandatory registration.

The migration of customers to other services within the same network will be easier once they have registered. Consider mobile money and post-paid telephony. The identity information required for both is similar to that required for pre-paid SIM card registration. Customer graduation to mobile money reduces churn: It is reported for Smart's money transfer in the Philippines that users of mobile money have a monthly churn rate of 0.5 percent compared to 3 percent for non-users (Scanlon, 2010, p. 44). Clustering of services with one provider increases the costs of switching to another, just as registration does. Moreover, if profitable prepaid customers can be identified, such customers can be migrated more easily to post-paid services, where a greater rent can be extracted by the telecom operator, because of reduced salience of costs. A recent study finds that prepaid customers at a northern European mobile service provider are more sensitive to average costs than post-paid customers, because salience of costs depends on the payment mechanism (Pirc, 2008). Increased price insensitivity in turn lowers price discipline. Again, the author has not found any academic studies on the competitive impact of registration in industrialized countries, which could act as guidepost. However, with respect to the competitive implications one could cautiously conclude that mandatory registration could be in the interest of telecom operators, as long as customers are not sophisticated, because it potentially lowers switching rates. Such lower rates also have an impact on consumer privacy: The lower the switching rate, the more integrated the profile becomes with the chosen operator. Registration bears costs for consumers and additionally raises concerns about location privacy: in future movement patterns can be more precisely linked to an individual identity. 


\section{Conclusions}

There is a noticeable trend of mandatory registration of users of prepaid SIM cards in SubSaharan Africa. More than 30 countries have started or are planning to register users of prepaid SIM cards. One immediate effect of registration is that the number of active cellular subscriptions drops due to disconnections. Moreover, penetration growth, measured as year-to-year changes in levels of mobile cellular subscriptions per 100 inhabitants are depressed due to increased paperwork. Customer identification can become, in particular, a constraint in countries with an insufficient identification infrastructure, if no alternative methods for identification are allowed. The share of prepaid subscriptions out of total subscriptions is, on average, around 97 percent for the sampled countries. The sheer size of the markets, therefore, merits a preliminary analysis of potential effects of mandatory registration.

Considered that changes were introduced only recently, the presented results are of a more preliminary character. Herein, evidence derived from a new panel dataset on 32 countries in Sub-Saharan Africa and penetration growth between 2000 and 2010 is presented. The FE model estimated herein controls for market saturation, political stability, regulatory quality, GDP growth rates as well as liberalization of the market. I use a proxy for the effectiveness of mandatory registration, which is a dummy of zero in the year of the deadline of registration, which switches to one the following year. The coefficient estimate carries the expected sign as direction of effect (negative) and cannot be contributed to chance at the $5 \%$ significance level. Short-term and long-term effects should be separated in future analyses: in the short-term potentially mostly dormant SIM cards are cleaned out. But with strict enforcement of identity verification by operators and an insufficient identification system, growth in mobile penetration could be also tamed in the long run. However, we need more years of observation or quarterly data in order to obtain further confirmation of the preliminary results presented herein.

Future work could contribute to a better understanding of the effects by building a theory of mandatory registration under competition in markets with network effects and consumers with privacy concerns. Consumer privacy concerns could exacerbate switching costs, if a consumer is not willing to share personal data with more than one operator. This is, of course, a trade-off, because the profile will become more complete at that provider.

The presented research opens a host of new questions: There are currently no works on mandatory registration of users in Europe and its impact on prepaid services. Such research 
would involve an extra effort of collecting information on regulations and prepaid subscriptions. Virtually no work exists on the impact of customer registration on rates of switching and competition among operators. More effort needs to be invested in a better understanding of legal protection and enforcement of mobile privacy in Africa. And much more effort needs to be invested in the collection of information on the design of registration procedures, strictness, enforcement and monitoring. This could lead to the creation of new variables that could be introduced into estimations. This paper can only be regarded as a first step into this area of research. A striking outcome derived from the screening of household surveys in Africa is that none asks respondents questions about registration and their privacy concerns. Another important point is that there is currently little empirical evidence that mandatory registration leads to a reduction of crime. There are ways of circumventing registration either by presenting fraudulent IDs, conducting identity theft, by stealing or swapping of phones. This casts doubts on the effectiveness of the measures with respect to their very rationale. Regulators should more more thoroughly analyze the costs and benefits of mandatory registration, because these could affect market dynamics in unintended ways. 


\section{References}

AfriqueAvenir.org (2010, September 27). Mozambique imposes compulsory registration of users of prepaid SIM cards, http://www.afriqueavenir.org/en/2010/09/27/mozambique-imposes-compulsory-registrationof-mobile-phone-users/

AfricaNews.com (2010, June 16). Africa SIM registration curbs mobile growth, www.africanews.com/site/Africa_Sim_registration_curbs_mobile_growth/list_messages/32772

Aker, J.C., \& Mibiti, I.M. (2010). Mobile phones and economic development in Africa. Journal of Economic Perspectives, 24 (3), 207-232. doi:10.1257/jep.24.3.207

Balancing Act (2011, April 19). Nigeria: Subscribers shun NCC's N6.1 billion SIM registration, http://allafrica.com/stories/201104190768.html

Balancing Act (2011, May 13). SIM registration in Africa: subscribers number down but what about revenue and ARPU? http://allafrica.com/stories/201105130900.html

Banerjee, A., \& Ros, A.J. (2004). Drivers of demand growth for mobile telecommunications services: evidence from international panel data, Massachusetts, U.S.: NERA Economic Consulting. Retrieved from: http://www.nera.com/extImage/DriversofDemandGrowth_Banerjee_Ros.pdf

Chatain. P.-L., Zerzan, A., Noor, W., Dannaoui, N., \& de Koker, L. (2011). Protecting mobile money against financial crimes-global policy challenges and solutions, Washington, DC: The World Bank.

Chuang, Y-F. (2006). Pull-and-suck effects in Taiwan mobile phone subscribers switching intentions, Telecommunications Policy, 35(1), 128-140. doi: 10.1016/j.telpol.2010.12.003

CPRST - Center for Policy Research on Science and Technology (2006). Privacy rights and prepaid communication service. Vancouver, Canada: Center for Policy Research on Science and Technology.

Dasgupta, K., Singh, R., Viswanathan, B. (2008). Social ties and their relevance to churn in mobile telecom networks, EDBT'08, March 25-30, 2008.

EACO - East African Communications Organization. (2010). Report on the proceedings of the 17th Congress of the East African Communications Organization held in Kempala, Uganda on 7th May 2010, Kempala, Uganda: East African Communications Organization.

Garbacz, C., \& Thompson Jr., H.G. (2007). Demand for telecommunication services in developing countries, Telecommunications Policy, 31(5), 276-289. doi: 10.1016/j.telpol.2007.03.007 
Gow, G.A., \& Parisi, J. (2008). Pursuing the anonymous user: Privacy rights and mandatory registration of prepaid mobile phones. Bulletin of Science, Technology \& Society, 28 (1), 60-68. doi: $10.1177 / 0270467607311487$

ITU - International Telecommunications Union. (2011). The role of ICT in advancing growth in least developed countries - Trends, challenges and opportunities. Geneva, Switzerland: International Telecommunication Union.

Jentzsch, N., Preibusch, S., Harasser A. (forthcoming). Study on monetizing privacy - An economic model for pricing personal information, Report for the European Network and Information Security Agency.

Klemperer, P. (1995). Competition when consumers have switching costs: An overview with applications to industrial organization, macroeconomics, and international trade. The Review of Economic Studies, 62(4): 515-539. doi: 10.2307/2298075

Lam, P.-L. \& Shiu, A. (2010). Economic growth, telecommunications development and productivity growth of the telecommunications sector: Evidence around the world, Telecommunications Policy, 34(4), 185-199. doi: 10.1016/j.telpol.2009.12.001

Levisse, A., Manuel, N., Sjolund, M. (2008, Feburary). Getting more from prepaid mobile services, McKinsey Quarterly. Retrieved from:

http://www.mckinseyquarterly.com/Getting_more_from_prepaid_mobile_services_2108

Loewenstein, G. (2000). Is More Choice Always Better? Mimeo, Carnegie Mellon University, http://www.andrew.cmu.edu/user/gl20/

GeorgeLoewenstein/Papers_files/pdf/too_much_choice.pdf

Malakata, M. (2010, May 14). SIM card registration stirs concern in Africa, Computerworld. Retrieved from: http://news.idg.no/cw/art.cfm?id=97BAE8AF-1A64-6A71-CE489938A5591ED4

Maicas, J.P., Polo, Y., Sese, J.F. (2009). Reducing the level of switching costs in mobile communications: The case of Mobile Number Portability, Telecommunications Policy, 33(9), 544-554. doi: 10.1016/j.telpol.2009.04.003

Minges, M. (1999). Mobile cellular communications in the Southern African region, Telecommunications Policy, 23(7-8), 585-593. doi: 10.1016/S0308-5961(99)00039-7

Musarurwa, T. (2011, May 10), Tele-density rate takes dip, The Herald Online. Retrieved from: 
www.herald.co.zw/index.php?option $=$ com_content\&view $=$ article\&id $=9567$ :

tele-density-rate-takes-dip\&catid=41:business\&Itemid=133

NERA - National Economic Research Associates. (2003). Switching Costs. Part one: Economic models and policy implications - A report prepared for the Office of Fair Trading and the Department of Trade and industry by National Economic Research Associates, Economic Discussion Paper 5 (April). Retrieved from: http://www.oft.gov.uk/shared_oft/reports/comp_policy/oft655.pdf

NetNews Publisher (2011, June 30). More than 95\% of mobile phone users in South Africa register SIM cards before government deadline. Retrieved from: http://www.netnewspublisher.com/more-than95-of-cell-phone-users-in-south-africa-register-sim-cards-before-government-deadline/

Owczarczuk, M. (2010). Churn models for prepaid customers in cellular telecommunication industry using large data marts, Expert Systems with Applications, 37, 4710-4712. doi: 10.1016/j.eswa.2009.11.083 Pirc, M. (2008). Determinants, contexts, and measurements of customer loyalty (unpublished doctoral dissertation). Universitat Pompeu Fabra, Barcelona, Spain.

Research ICT Africa. (2008). A Survey of ICT access and usage in Ethiopia: Policy implications, ICT Policy Brief, No. 1. Retrieved from: http://www.researchictafrica.net/publications.php

Scanlon, M. (2010). Tackling prepaid churn in multiple SIM markets remains a challenge, Africa Telecoms (AT), Issue 7 (2010): 43-44.

Telegeography (2011, November 29). NCC registers 93m SIMs, will begin disconnection from 1 January, http://www.telegeography.com/products/commsupdate/articles/2011/11/29/ncc-registers-93m-simswill-begin-disconnection-from-1-january/

Waverman, L., Meschi, M., Fuss, M. (2005). The impact of telecoms on economic growth in developing countries. Retrieved from: http://www.ictregulationtoolkit.org/en/Publication.3532.html

Wesolowski, A.P. \& Eagle, N. (2010). Parameterizing the dynamics of slums, AAAI Spring Symposium 2010 on Artificial Intelligence for Development (AI-D). Retrieved from: http://ai-d.org/pdfs/Wesolowski.pdf

Wood, N. (2010, August 18). Greek mobile customers in freefall on continuing economic weakness. Total Telecom. Retrieved from: www.totaltele.com/view.aspx?ID=457996 
Table 1: Mandatory Registration Measures in Sub-Saharan Africa

\begin{tabular}{|c|c|c|c|}
\hline No & Country & Start year registration & "Deadline registration \\
\hline 1 & Angola & $\ldots$ & $\ldots$ \\
\hline 2 & Benin & 2010 & 2010 \\
\hline 3 & Botswana & 2008 & 2009 \\
\hline 4 & Burkina Faso & 2008 & 2011 \\
\hline 5 & Burundi & 2011 & 2011 \\
\hline 6 & Cameroon & 2009 & 2009 \\
\hline 7 & Cape Verde & $\ldots$ & $\ldots$ \\
\hline 8 & Central African Rep. & 2009 & $\ldots$ \\
\hline 9 & Chad & 2011 & 2011 \\
\hline 10 & Comoros & $\ldots$ & $\ldots$ \\
\hline 11 & Congo, Dem. Rep. & 2008 & 2009 \\
\hline 12 & Congo, Republic of & 2011 & 2011 \\
\hline 13 & Côte d'Ivoire & 2009 & 2010 \\
\hline 14 & Djibouti & $\ldots$ & $\ldots$ \\
\hline 15 & Equatorial Guinea & $\ldots$ & $\ldots$ \\
\hline 16 & Eritrea & $\ldots$ & $\ldots$ \\
\hline 17 & Ethiopia & $\ldots$ & $\ldots$ \\
\hline 18 & Gabon & 2010 & 2010 \\
\hline 19 & Gambia & 2011 & 2011 \\
\hline 20 & Ghana & 2010 & 2011 \\
\hline 21 & Guinea & $\ldots$ & $\ldots$ \\
\hline 22 & Guinea-Bissau & $\ldots$ & $\ldots$ \\
\hline 23 & Kenya & 2010 & 2010 \\
\hline 24 & Lesotho & $\ldots$ & $\ldots$ \\
\hline 25 & Liberia & 2011 & 2011 \\
\hline 26 & Madagascar & $\ldots$ & $\ldots$ \\
\hline 27 & Malawi & No policy & No policy \\
\hline 28 & Mali & $\ldots$ & $\ldots$ \\
\hline 29 & Mauritania & $\ldots$ & $\ldots$ \\
\hline 30 & Mauritius & 2006 & 2006 \\
\hline 31 & Mozambique & 2010 & 2010 \\
\hline 32 & Namibia & No policy & No policy \\
\hline 33 & Niger & 2009 & 2010 \\
\hline 34 & Nigeria & 2011 & 2011 \\
\hline 35 & Rwanda & 2012 & 2012 \\
\hline 36 & Sao Tome \& Principe & $\ldots$ & $\ldots$ \\
\hline 37 & Senegal & 2006 & 2007 \\
\hline 38 & Seychelles & 2009 & 2009 \\
\hline 39 & Sierra Leone & 2009 & 2010 \\
\hline 40 & Somalia & $\ldots$ & $\ldots$ \\
\hline 41 & South Africa & 2009 & 2011 \\
\hline 42 & Sudan & 2008 & 2008 \\
\hline 43 & Swaziland & $\ldots$ & $\ldots$ \\
\hline 44 & Tanzania & 2009 & 2009 \\
\hline 45 & Togo & 2011 & 2011 \\
\hline 46 & Uganda & 2011 & 2012 \\
\hline 47 & Zambia & No policy & No policy \\
\hline 48 & Zimbabwe & 2010 & 2010 \\
\hline
\end{tabular}


Table 2: Start Year of Mandatory Registration of Prepaid Subscribers

\begin{tabular}{r|r|r|r|r|r}
\hline \hline \multicolumn{1}{c|}{2006} & \multicolumn{1}{c|}{2008} & \multicolumn{1}{c|}{2009} & \multicolumn{1}{c|}{2010} & \multicolumn{1}{c}{2012} \\
\hline \hline Senegal & Botswana & Cameroon & Benin & Burundi & Rwanda \\
\hline Mauritius & Burkina Faso & Central Afr. Rep. & Gabon & Chad & \\
\hline & Congo, Dem. Rep. & Côte d'Ivoire & Ghana & Congo, Rep. of & \\
\hline & Sudan & Niger & Kenya & Gambia & \\
\hline & & Seychelles & Mozambique & Liberia & \\
\hline & & Sierra Leone & Zimbabwe & Nigeria & \\
\hline & & South Africa & & Togo & \\
\hline & & Tanzania & & Uganda & \\
\hline
\end{tabular}


Table 3: Data Sources and Descriptions

\begin{tabular}{|c|c|c|}
\hline Variable & Sources & Description \\
\hline $\begin{array}{l}\text { Share } \quad \text { of } \\
\text { prepaid } \\
\text { subscribers } \\
\text { in total } \\
\text { mob. sub- } \\
\text { scriptions }\end{array}$ & $\begin{array}{l}\text { ITU; } \text { Year: } \\
2008\end{array}$ & $\begin{array}{l}\text { Prepaid subscriptions (\%) of total mobile phone subscrip- } \\
\text { tions. Numbers refer to active SIM cards and not to natural } \\
\text { persons. Year: } 2008, \text { n/a for other years. }\end{array}$ \\
\hline $\begin{array}{ll}\text { GDP } & \text { per } \\
\text { capita } & \\
(2008) & \end{array}$ & $\begin{array}{l}\text { CIA World } \\
\text { Fact Book; } \\
\text { Year: } 2008\end{array}$ & $\begin{array}{l}\text { Gross Domestic Product per capita (2008) at PPP US\$. The } \\
\text { variable is used in the Fig. } 1 .\end{array}$ \\
\hline $\begin{array}{l}\text { Growth in } \\
\text { mobile pen- } \\
\text { etration }\end{array}$ & $\begin{array}{l}\text { ITU, ICT } \\
\text { Indicators } \\
\text { Database; } \\
\text { Years: } \\
\text { 2000-2010 }\end{array}$ & $\begin{array}{l}\text { First difference of mobile subscriptions per } 100 \text { inhabitants. } \\
\text { Numbers refer to active pre- and post-paid SIM cards and } \\
\text { not to natural persons. }\end{array}$ \\
\hline $\begin{array}{l}\text { GDP } \\
\text { growth } \\
\text { rates }\end{array}$ & $\begin{array}{l}\text { IMF, Years: } \\
2000-2010\end{array}$ & $\begin{array}{l}\text { Year-to-year percentage change of Gross Domestic Product } \\
\text { (GDP) at constant prices. }\end{array}$ \\
\hline $\begin{array}{l}\text { Effectiveness } \\
\text { of regis- } \\
\text { tration } \\
\text { (deadline) }\end{array}$ & $\begin{array}{l}\text { Author's } \\
\text { compila- } \\
\text { tion, Years: } \\
2000-2010\end{array}$ & $\begin{array}{l}\text { Proxy for the effect the deadline of mandatory registration, } \\
\text { which is the year of the deadline plus one year to account } \\
\text { for effectiveness. Sources: News sources in English, French } \\
\text { and Portuguese African media and as websites of regulators } \\
\text { in SSA. }\end{array}$ \\
\hline $\begin{array}{l}\text { Regulatory } \\
\text { Quality }\end{array}$ & $\begin{array}{l}\text { World } \\
\text { Bank; } \\
\text { Years: } \\
1996-2010\end{array}$ & $\begin{array}{l}\text { This is a World Bank indicator, which reflects the statisti- } \\
\text { cal compilation of responses on the quality of governance, } \\
\text { i.e. regulatory quality given by firms, citizen and expert } \\
\text { respondents. The point estimate is measured in units rang- } \\
\text { ing from }-2.5 \text { to } 2.5 \text {, higher values corresponding to better } \\
\text { governance. }\end{array}$ \\
\hline $\begin{array}{l}\text { Political } \\
\text { Stability }\end{array}$ & $\begin{array}{l}\text { World } \\
\text { Bank; } \\
\text { Years: } \\
1996-2010\end{array}$ & $\begin{array}{l}\text { This is a World Bank indicator, which reflects the statistical } \\
\text { compilation of responses on the quality of governance, i.e. } \\
\text { political stability given by firms, citizen and expert respon- } \\
\text { dents. The point estimate is measured in units ranging from } \\
-2.5 \text { to } 2.5 \text {, higher values corresponding to better governance. }\end{array}$ \\
\hline $\begin{array}{l}\text { Levels of } \\
\text { mobile } \\
\text { penetration }\end{array}$ & $\begin{array}{l}\text { ITU, ICT } \\
\text { Indicators } \\
\text { Database, } \\
\text { Years: } \\
\text { 2000-2010 }\end{array}$ & $\begin{array}{l}\text { IV: Mobile cellular subscriptions per } 100 \text { inhabitants. Num- } \\
\text { bers refer to active SIM cards and not to natural persons. } \\
\text { Variable is used as proxy for market saturation. }\end{array}$ \\
\hline $\begin{array}{l}\text { Telecom } \\
\text { liberaliza- } \\
\text { tion }\end{array}$ & $\begin{array}{l}\text { GSMA, } \\
\text { Years: } \\
1995-2009\end{array}$ & $\begin{array}{l}\text { IV: The status of int. voice gateway licensing, compiled by } \\
\text { Paul Hamilton, where: } 0=\text { Monopoly, } 0.5=\text { Deregulated, } 1 \\
=\text { liberalized. The author gratefully acknowledges the pro- } \\
\text { vision by Professor Jenny Aker. } 2010 \text { was completed by the } \\
\text { author by taking the } 2009 \text { value as proxy for } 2010 \text {. }\end{array}$ \\
\hline
\end{tabular}


Table 4: Summary Statistics on Confirmed Sample

\begin{tabular}{|c|c|c|c|c|c|}
\hline Variable & Mean & Std. Dev. & Minimum & Maximum & Observations \\
\hline \multicolumn{6}{|l|}{ Level mob. penetration, D1 } \\
\hline overall & 5.339335 & 5.634017 & -1.18 & 38.88 & $\mathrm{~N}=316$ \\
\hline between & & 2.666584 & 1.346 & 10.512 & $\mathrm{n}=32$ \\
\hline within & & 4.97788 & -5.412666 & 35.26634 & T-bar $=9.875$ \\
\hline \multicolumn{6}{|l|}{ GDP growth } \\
\hline overall & .0076288 & .1840797 & -.9845185 & .4950391 & $\mathrm{~N}=350$ \\
\hline between & & .0477134 & -.0617628 & .1179729 & $\mathrm{n}=32$ \\
\hline within & & .177962 & -.964814 & .384695 & T-bar $=10.9375$ \\
\hline \multicolumn{6}{|l|}{ Level mob. penetration } \\
\hline overall & 22.32908 & 26.94653 & .02 & 135.91 & $\mathrm{~N}=349$ \\
\hline between & & 18.41839 & 3.84 & 79.92182 & $\mathrm{n}=32$ \\
\hline within & & 19.86761 & -24.60273 & 92.48545 & T-bar $=10.9063$ \\
\hline \multicolumn{6}{|l|}{ Regulatory quality } \\
\hline overall & -.6024827 & .6245589 & -2.252721 & .8468239 & $\mathrm{~N}=320$ \\
\hline between & & .6156691 & -1.99866 & .6131373 & $\mathrm{n}=32$ \\
\hline within & & .1473755 & -1.176835 & -.0531604 & $\mathrm{~T}=10$ \\
\hline \multicolumn{6}{|l|}{ Political stability } \\
\hline overall & -.5782193 & .970055 & -2.700543 & 1.189204 & $\mathrm{~N}=320$ \\
\hline between & & .9360896 & -2.242817 & .9215636 & $\mathrm{n}=32$ \\
\hline within & & .299107 & -1.995148 & .4300014 & $\mathrm{~T}=10$ \\
\hline \multicolumn{6}{|l|}{ Telecom lib. } \\
\hline overall & .5525568 & .4537834 & 0 & 1 & $\mathrm{~N}=352$ \\
\hline between & & .2842412 & 0 & 1 & $\mathrm{n}=32$ \\
\hline within & & .3569708 & -.3565341 & 1.27983 & $\mathrm{~T}=11$ \\
\hline \multicolumn{6}{|l|}{ Dummy registration } \\
\hline overall & .0482955 & .214695 & 0 & 1 & $\mathrm{~N}=352$ \\
\hline between & & .0951626 & 0 & .3636364 & $\mathrm{n}=32$ \\
\hline within & & .1931218 & -.3153409 & .9573864 & $\mathrm{~T}=11$ \\
\hline
\end{tabular}


Table 5: Correlation Coefficients on Confirmed Sample

\begin{tabular}{l|l|l|l|l|l|l|l}
\hline \hline Variable & $\begin{array}{l}\text { Level } \\
\text { mob. } \\
\text { penetr. } \\
\text { D1 }\end{array}$ & $\begin{array}{l}\text { GDP } \\
\text { growth }\end{array}$ & $\begin{array}{l}\text { Level } \\
\text { mobile } \\
\text { pene- } \\
\text { tration }\end{array}$ & $\begin{array}{l}\text { Reg. } \\
\text { quality }\end{array}$ & $\begin{array}{l}\text { Political } \\
\text { stability }\end{array}$ & $\begin{array}{l}\text { Telecom } \\
\text { liberal. }\end{array}$ & $\begin{array}{l}\text { Dummy } \\
\text { registra- } \\
\text { tion }\end{array}$ \\
\hline \hline $\begin{array}{l}\text { Level mob. } \\
\text { penetr., D1 }\end{array}$ & 1 & & & & & & \\
\hline $\begin{array}{l}\text { GDP } \\
\text { growth }\end{array}$ & .0176 & 1 & & & & & \\
\hline $\begin{array}{l}\text { Level mob. } \\
\text { penetration }\end{array}$ & $.7034^{*}$ & .1586 & 1 & & & & \\
\hline $\begin{array}{l}\text { Regulatory } \\
\text { quality }\end{array}$ & $.2124^{*}$ & .08 & $.3571^{*}$ & 1 & & & \\
\hline $\begin{array}{l}\text { Political } \\
\text { stability }\end{array}$ & $.2751^{*}$ & .0879 & $.4202^{*}$ & $.6741^{*}$ & 1 & & \\
\hline $\begin{array}{l}\text { Telecom } \\
\text { liberaliza- } \\
\text { tion }\end{array}$ & $.2066^{*}$ & $.1992^{*}$ & $.3071^{*}$ & -.0495 & -.0435 & 1 & \\
\hline $\begin{array}{l}\text { Dummy } \\
\text { registration }\end{array}$ & .1148 & .048 & $.3398^{*}$ & .1173 & .0382 & .1201 & 1 \\
\hline \hline
\end{tabular}


Table 6: Fixed Effects Models

\begin{tabular}{|c|c|c|c|c|}
\hline \multirow{3}{*}{$\begin{array}{lr}\text { DV: } & \text { Y-t-y } \\
\text { chgs. } & \text { in } \\
\text { mob.pentr. }\end{array}$} & Modol 1 & Modol ? & & \\
\hline & Mlodel 1 & Mlodel 2 & Mlodel 3 & Mlodel 4 \\
\hline & Confirmed Sample & Confirmed Sample & Confirmed Sample & Confirmed Sample \\
\hline \multirow{2}{*}{$\begin{array}{l}\text { GDP } \\
\text { growth }\end{array}$} & 6.7451411 & 9.1104322 & 9.118959 & 9.248009 \\
\hline & $(8.6056)$ & $(9.3691)$ & $(9.6135)$ & $(9.0876)$ \\
\hline \multirow{2}{*}{$\begin{array}{l}\text { Level } \\
\text { mob.pentr. }\end{array}$} & $.16545953^{* * *}$ & $.19547456^{* * *}$ & $.19545666^{* * *}$ & $.19509478^{* * *}$ \\
\hline & $(0.0439)$ & $(0.0449)$ & $(0.0453)$ & $(0.0469)$ \\
\hline \multirow{2}{*}{$\begin{array}{l}\text { Dummy } \\
\text { reg. }\end{array}$} & $-4.662463^{*}$ & $-4.575469^{*}$ & $-4.5789673^{*}$ & $-4.5974388^{*}$ \\
\hline & $(1.9344)$ & $(1.9743)$ & $(1.9658)$ & $(1.8731)$ \\
\hline \multirow{2}{*}{$\begin{array}{l}\text { Regulatory } \\
\text { quality }\end{array}$} & & 3.1186441 & 3.12078 & 3.094077 \\
\hline & & $(2.8226)$ & $(2.852)$ & $(2.7996)$ \\
\hline \multirow{2}{*}{$\begin{array}{l}\text { Political } \\
\text { stability }\end{array}$} & & & -.01341234 & -.01063935 \\
\hline & & & $(1.0896)$ & $(1.1018)$ \\
\hline \multirow{2}{*}{$\begin{array}{l}\text { Telco liber- } \\
\text { alization }\end{array}$} & & & & .16865243 \\
\hline & & & & $(1.6509)$ \\
\hline \multirow[t]{2}{*}{ Constant } & .53735578 & 1.9191484 & 1.9104869 & 1.8348366 \\
\hline & $(0.7949)$ & $(2.1883)$ & $(2.2776)$ & $(2.0432)$ \\
\hline $\begin{array}{l}\text { Year fixed } \\
\text { effects }\end{array}$ & omitted & omitted & omitted & omitted \\
\hline $\begin{array}{l}\text { Country } \\
\text { fixed effects }\end{array}$ & omitted & omitted & omitted & omitted \\
\hline$\overline{\mathrm{N}}$ & 316 & 284 & 284 & 284 \\
\hline $\mathrm{r} 2$ & .51837031 & .51314905 & .51314951 & .51321716 \\
\hline $\mathrm{r} 2 \_\mathrm{a}$ & .49929587 & .49159108 & .48970856 & .48788274 \\
\hline
\end{tabular}

